\title{
Black Subjects
}





\section{Black SubJects \\ Identity Formation in the Contemporary \\ Narrative of Slavery}

ArLene R. KeIzer

Cornell University Press

Ithaca and London 


\section{Copyright $\odot 2004$ by Cornell University}

Portions of Black Subjects have been previously published as follows:

An earlier version of chapter 1 appeared in African American Review 33.1:105-23.

A portion of chapter 5 appeared in American Literature 72.2:387-416.

Segments of the conclusion appeared in Michigan Quarterly Reivew 40.2:431-36.

All rights reserved. Except for brief quotations in a review, this book, or parts thereof, must not be reproduced in any form without permission in writing from the publisher. For information, address Cornell University Press, Sage House, 512 East State Street, Ithaca, New York $1485^{\circ}$.

First published 2004 by Cornell University Press

First printing, Cornell Paperbacks, 2004

Printed in the United States of America

Design by Scott Levine

Library of Congress Cataloging-in-Publication Data

Keizer, Arlene R.

Black subjects : identity formation in the contemporary narrative of slavery / Arlene R. Keizer.

p. cm.

Includes bibliographical references and index.

ISBN o-80 14-4095-5 (cloth : alk. paper) — ISBN o-801 4-8904-o (pbk. : alk. paper)

1. American fiction-2oth century-History and criticism. 2. Slavery in literature. 3. Caribbean literature (English)-History and criticism. 4. Walcott, Derek. Dream on Monkey Mountain. 5. Identity (Psychology) in literature. 6. African Americans in literature. 7. Slave trade in literature. 8. Blacks in literature. I. Title.

$$
\begin{aligned}
& \mathrm{PS}_{374} \cdot \mathrm{S}_{5} 8 \mathrm{~K}_{45} 2004 \\
& 813^{\prime} \cdot 5^{\circ} \mathrm{O}_{355^{2}-\mathrm{dc} 22}
\end{aligned}
$$

2004001133

Cornell University Press strives to use environmentally responsible suppliers and materials to the fullest extent possible in the publishing of its books. Such materials include vegetable-based, low-VOC inks and acid-free papers that are recycled, totally chlorine-free, or partly composed of nonwood fibers. For further information, visit our website at www.cornellpress.cornell.edu.

Cloth printing

Paperback printing
10987654321

10987654321 
This book is dedicated to my beloved mother Annette R. Keizer and to my beloved mentor and friend Barbara T. Christian

$$
\text { (1943-2000) }
$$

Oh, we have paid for our children's place in the world again, and again ...

Dessa Rose, Sherley Anne Williams 

So it is important to undo whatever words obscure the fact that slave law was at least as fragmenting and fragmented as the bourgeois world view - and in a way that has persisted to this day, cutting across all ideological boundaries. As "pure will" signifies the whole bourgeois personality in the latter, so wisdom, control, and aesthetic beauty signify the whole white personality in the former. The slavemaster and the burgermeister are not so very different, when expressed in those terms. The reconciling difference is that in slave law the emphasis is really on the inverse rationale: that irrationality, lack of control, and ugliness signify the whole slave personality. ... In my search for roots I must assume, not just as history but as an ongoing psychological force, that irrationality, lack of control, and ugliness signify not just the whole slave personality, not just the whole black personality, but me...

To look is ... to make myself vulnerable; yet not to look is to neutralize the part of myself that is vulnerable. I look in order to see, and so I must look. Without that directness of vision, I am afraid I shall will my own blindness, disinherit my own creativity, and sterilize my own perspective of its embattled, passionate insight.

Patricia J. Williams, The Alchemy of Race and Rights

The themes, then, that I wish to pursue here are centered on the relation between the writing of history as prediction and as retrospection. The history that will be is, after all, as much how we recount what happened as how we project a future; the history that will be is, inevitably, a history of the present, that divided site that must look both ways at once.

Jonathan Goldberg, "The History That Will Be" 
